\title{
Spatio-temporal distribution of preimaginal black flies (Diptera: Simuliidae) in streams of a sub-basin of the Uruguay river basin, southern Brazil
}

\author{
Patricia Maria Limberger ${ }^{\bowtie}$, David Augusto Reynalte Tataje $\odot$, Darlan Novick $\odot$, \\ Luiz Carlos Marmilicz Junior $₫$ \& Milton Norberto Strieder $\odot$
}

Universidade Federal da Fronteira Sul, Campus Cerro Largo, RS, Brazil.

\section{EntomoBrasilis 14: e946 (2021)}

\section{Edited by:}

Alberto Moreira Silva-Neto

Article History:

Received: 27.v.2021

Accepted: 18.viii.2021

Published: 01.iX.2021

Corresponding author:

Patricia Maria Limberger

乃 patiilimberger@hotmail.com

Funding agencies:

Without funding declared

\begin{abstract}
Adult females of most black flies species (Diptera, Simuliidae) exhibit a blood-sucking habit. Immature stages develop in water courses and are important in the ecology of lotic environments. We aim to understand the distribution of immature simuliids in the hydrographic sub-basin of the Comandaí river, in Northwest of Rio Grande do Sul, Brazil. For that purpose, simuliids were sampled in three stretches (source, intermediate and mouth) of nine streams, distributed along the three main regions of the sub-basin. Evaluations of the influence of abiotic factors in different spatial and temporal scales were made. Sampling was carried out in two seasons: between September and November 2016 (spring), and between April and July 2017 (autumn). In total, 17,146 individuals were sampled (larvae of last instars and pupae), which resulted in the identification of eleven Simuliidae species. The most abundant species were Simulium pertinax Kollar (77.55\%), followed by Simulium incrustatum Lutz (14.56\%) and Simulium subpallidum Lutz (2.35\%). Regarding the identification of indicator species, S. pertinax, Simulium jujuyense Paterson \& Shannon, S. subpallidum and Simulium orbitale Lutz stood out in mouth stretches, and Simulium rubrithorax Lutz in source stretches. Environmental variables such as conductivity, altitude, canopy cover and stream width were interpreted as important conditioning factors for the distribution of simuliid immature stages. In general, we concluded that Simuliidae are more abundant during spring in the study area, mainly downstream. This information may contribute to the implementation of efficient measures to control species of health importance in southern Brazil.
\end{abstract}

Keywords: Aquatic insects; Lotic environments; Community ecology; Neotropical; Simuliid.

\begin{abstract}
Dimuliidae (Diptera: Culicomorpha) comprises 2,401 species (2,384 living and 17 fossil), representing a net increase of 53 living species since the previous [2020] (ADLER 2021). These insects, commonly known as black flies occur in all zoogeographic regions (except Antarctica) and, in most species, females present a hematophagous feeding habit (CRosskey 1990; HamAda et al. 2002). Immature stages (eggs, larvae and pupae) develop in lotic aquatic environments and are characterized by the capacity of colonizing new substrates in a short period of time (KIEL et al.1998; Malmovist et al. 1999; Adler \& McCReadie 2019).
\end{abstract}

In the aquatic environment, simuliids play an important role in trophic relationships, acting as organic matter filter feeders and serving as the basis of the food chain for fish, crustaceans and other insect larvae (CURRIE \& AdLER 2008; FerreIRA et al. 2020). Adults live in the terrestrial environment and are known for their medical-veterinary importance, since the female's hematophagous habit causes allergic reactions, causing discomfort in humans and domestic animals (STRIEDER \& CoRSEUIL 1992; SARIÖZKAn et al. 2014). Several species can be vectors of parasites such as the nematodes Onchocerca volvulus (Leuckart), mainly in Sub-Saharan Africa (SSA), some Latin American countries and Yemen and Mansonella ozzardi (Manson), in Brazil, Colombia and Guyana (BusARI et al. 2021; LópEZ-PENÃ et al. 2021).

According to BAPTISTA et al. (2014), Brazilian studies regarding communities' diversity in lotic environments are generally focused on the ecology of biological organisms, addressing the composition and spatial distribution of species on a local scale, restricted to a certain river stretch or micro-basin. Regarding the spatio-temporal distribution of simuliids, regions that comprise the Central Amazon (SANTOS \& MARINHO 2021) and Atlantic Forest biome (BERTAZO at al. 2013; Docile et al. 2015), are the ones that concentrate the higher number of recent studies conducted in Brazil, followed by the Cerrado biome (FIGUEIRó et al. 2012, 2014, 2015, 2020).

Studies on the distribution of simuliids in hydrographic basins allow us to understand the general patterns of these aquatic insects' spatial organization in lotic environments, since the occurrence of immature stages is influenced by a series of local abiotic factors such as: watercourse flow, availability of substrate for immature fixation, substances dissolved in water, human action and the degree of each species' specialization to these factors (AdLER \& KIM 1984; Corkum \& Currie 1987; Moreira et al. 1994; Coscarón et al. 1996; Hamada \& McCreadie 1999; Hamada et al. 2002; Pepinelli et al. 2005; Strieder et al. 2006; Tongjura et al. 2015; Adler \& McCREADIE 2019). Seasonality also plays an important role in the local distribution of species, since the rainy and dry seasons present distinct patterns of diversity and regional abundance, where is often observed a higher abundance during the rainy season (PEPINELLI et al. 2005; FIGUEIRó et al. 2014; SRISUKa et al. 2015; PAVITRA et al. 2020; Figueiró et al. 2020; JACOB et al. 2021; SRISUKa et al. 2021).

COSCARón (1991) mention that the South and Southeast regions of Brazil present severe problems related by simuliids, 
due to the high occurrence rates of anthropophilic species (FIGUeIRó \& GIL-AzEVEdo 2010). Among the anthropophilic species occurring in southern Brazil, Simulium pertinax Kollar is the one with the highest population rates (STRIEDER et al. 2006). Thus, the knowledge on the distribution of immature individuals in hydrographic sub-basins are essential for the efficient management of freshwater ecosystems and control of epidemiological important species (ARAújo-CoUtinHO et al. 1999). In this sense, our main goal was to identify the local diversity of Simuliidae and to investigate how abiotic variables may influence the spatio-temporal distribution of species inhabiting the main streams from the Comandaí river sub-basin, upper region of the Uruguay river basin (Brazil).

\section{MATERIAL AND METHODS}

Study Area. We covered the main streams from the Comandaí river sub-basin, which is located in Rio Grande do Sul state, Brazil. The basin has a total area of $11,056.23 \mathrm{~km}^{2}$. Its sources are located at about $400 \mathrm{~m}$ altitude, and its mouth at $90 \mathrm{~m}$. The Comandaí river has a total course of $170 \mathrm{~km}$ and an average slope of around $2.3 \mathrm{~m} / \mathrm{km}^{2}$ (DORA 2013).

The main economic activities in the sub-basin are related to agriculture and livestock production, where the cultivation of corn, soybeans and wheat are widespread throughout the region. Livestock, on the other hand, is characterized by the production of beef and dairy cattle, and to a lesser extent, pig and poultry farming (BRASIL 2011). The tributary streams from the upper Uruguay river reg ion are mostly short and quite steep, which make them attractive for tourism.

According to the Socioeconomic Atlas of Rio Grande do Sul (RıO GRANDE DO SUL 2002), the region's climate is subtropical, classified as humid mesothermal (Köppen classification), the temperature is very variable, with hot summers and severe winters, with the occurrence of frosts and eventual snowfall. The average temperature varies between 15 and $18{ }^{\circ} \mathrm{C}$, with minimums of $-10^{\circ} \mathrm{C}$ and maximum of $40{ }^{\circ} \mathrm{C}$. Regarding precipitation, the region presents a relatively balanced distribution of rainfall throughout the year, due to oceanic air masses entering the State of Rio Grande do Sul (Rıo Grande DO SUL 2002).

In order to survey the species richness and better understand the local distribution of simuliids in the Comandaí river subbasin, 27 sample points were selected across nine main streams, based on their accessibility, presence of rapids, altitude and stretch of watercourse. The sample design comprised the following streams: Comandaizinho (Co), das Pedras (Pe), Giruá (Gi), Lambedor (La), Fundão (Fu), Laranjeira (Lr), Pessegueiro (Ps), Luiza (Lu) and Lavínea (Lv), with three points in each stream: Source (1), Intermediate (2), and Mouth (3). Three streams are located in the Upper Comandaí region $(A)$, three in the Middle Comandaí $(M)$ and three in the Lower Comandaí (B). Thus, the twenty-seven sampling points were expressed as: CoA1, CoA2, CoA3, PeA1, PeA2, PeA3, GiA1, GiA2, GiA3, LaM1, LaM2, LaM3, FuM1, FuM2, FuM3, LrM1, LrM2, LrM3, PsB1, PsB2, PsB3, LuB1, LuB2, LuB3, LvB1, LVB2 and LvB3 (Figure 1).

Sampling. Spring is the season where the greatest species richness, as well as higher abundance are observed for Simuliidae species in southern Brazil (Strieder \& Corseuil 1992). Fleming et al. (1986) highlighted the importance of the transitioning climates that occur between summer and winter due to their distinct characteristics. Thus, we decided to conduct the sampling in two seasons: autumn and spring, allowing a temporal comparison between two periods of the year, since these are periods of greater and lesser occurrence of simuliids in southern Brazil. The first sampling occurred between the months of September and November 2016, during Spring, and the second sampling occurred during autumn, between April and July 2017.

Sampling included only immature stages (larvae and pupae) and was performed downstream, in stretches of about 100 meters, for 40 minutes. Physicochemical and landscape factors were collected at all study points, right after sampling the immature simuliid individuals. A portable multiparameter probe was used to measure environmental parameters at each station, such as: water temperature $\left({ }^{\circ} \mathrm{C}\right)$,

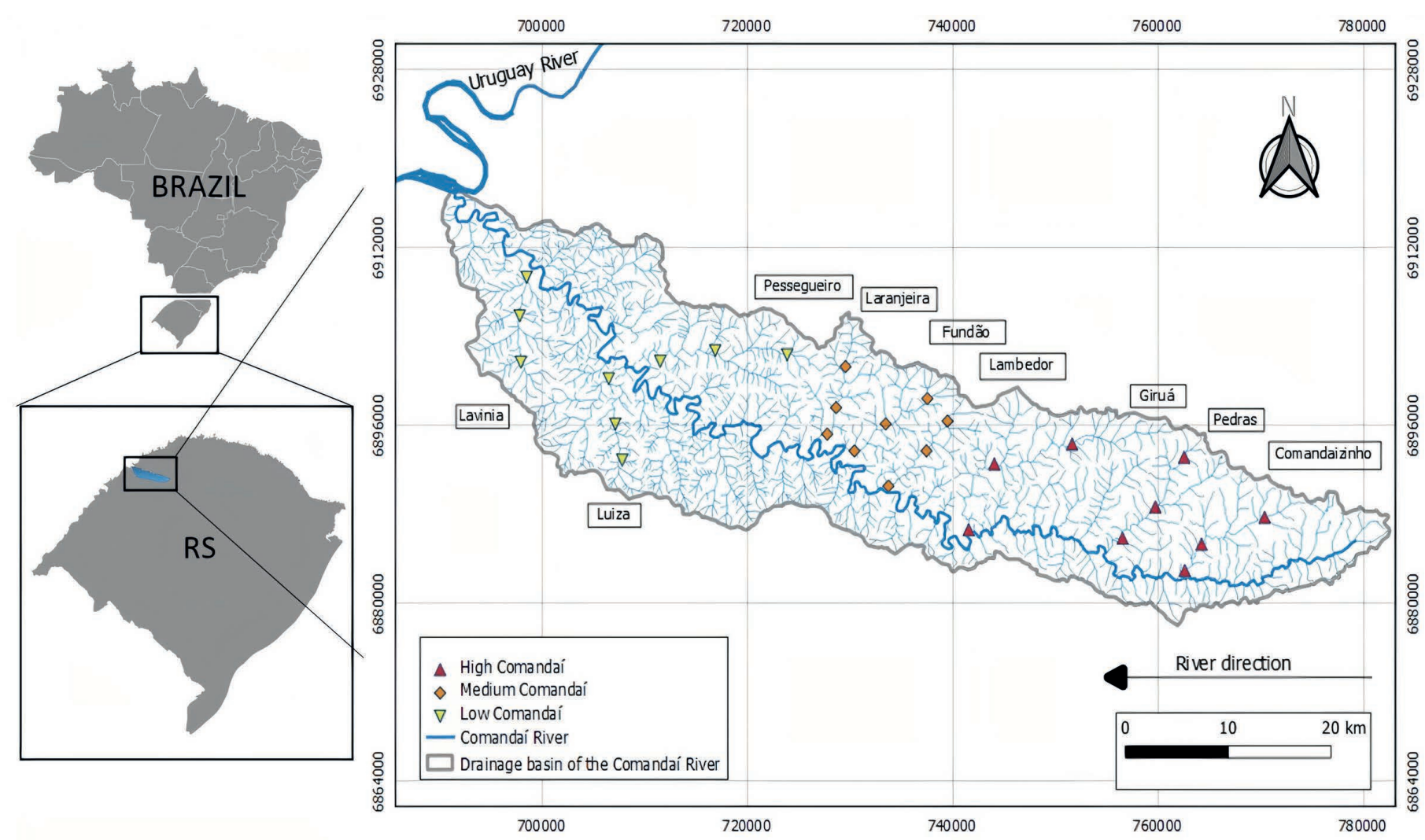

Figure 1. Distribution map of the twenty-seven simuliid sampling points in the Comandaí river basin, Rio Grande do Sul, Brazil. 
$\mathrm{pH}$, electrical conductivity ( $\mu \mathrm{S} / \mathrm{cm})$, dissolved oxygen (\%), also and atmospheric pressure $(\mathrm{mmHg})$. Stream's width was also estimated using a measuring tape. Through the Google Earth Pro browser, we obtained the geographical coordinates and respective altitudes of sampling points. Such procedures follow the methods proposed by McCREADIE \& AdLER (2006).

Screening and identification of biological material. The collection of specimens was done manually, with the aid of brush and tweezers to facilitate their extraction from the substrate and flasks containing $96^{\circ}$ alcohol for storage. A screening process for the collected biological material was used prior to species identification, since the collection procedures were not selective for Simuliidae. Thus, we removed plant debris and other macroinvertebrate taxa from samples.

StRIeder \& Py-Daniel (1999) states that younger larval forms do not present the specific characteristics to ensure identification at the species level. Thus, all simuliid larvae were classified according to morphotype, and only individuals with wellformed branchial histoblast were considered for species identification.

For species identification we followed taxonomic keys, especially those proposed by COSCARón (1991) and StRIEDER \& CORSEUIL (1992). The most up-to-date global taxonomic inventory (ADLER 2021) was verified to check synonymous species. After identification, we deposited the material in the biological collection of the Zoology laboratory from the Universidade Federal da Fronteira Sul (UFFS) - Cerro Largo campus.

Data analysis. We assumed that the number of sampled species represents the biological diversity of Simuliidae from the area.

In order to determine the taxonomic composition and abundance of species form different regions of the basin (upper, middle and lower) and in different stretches of the streams (source, intermediate and mouth) we calculated the frequency of occurrence (FO\%) of each species in a given sampling point in relation to all others, for both sampling seasons.

The permutational multivariate analysis of variance (PERMANOVA) was used to understand the interactions of simuliid composition across streams and between seasons, and a $T$ test was used to analyze the composition of similar simuliid species between streams' stretches. The Monte Carlo Significance Test was used to highlight spatial and temporal indicator species. Regarding the spatial-temporal variation of species abundance and richness in relation to the season and stream, we used the bifactorial Analysis of Variance (ANOVA) and Tukey's post-hoc test was used in the case of differences in ANOVA. Before using ANOVA, the normality pattern of the data was evaluated using the Kolmogorov-Smirnov test, as well as the homogeneity of variances with the Levene test.

In order to select the abiotic variables that better explain the results, and then evaluate the relationship between simuliid diversity and environmental variables, we used the forward selection method. To stabilize and normalize as variances, the observed values, except $\mathrm{pH}$, were log transformed $(\log (x+1))$. The structure of the simuliid assemblage was evaluated through a Canonical Correspondence Analysis - CCA. These analyzes allowed us to visualize the most important relationships between all variables. The same data set was subjected to the MRPP (Multiple Response Permutation Procedure) permutation test, in order to compare the differences across the different regions and streams' stretches. All analyzes were performed using the PC
ORD software (version 5.0) and with a significance of $\alpha \leq 0.05$.

\section{RESULTS}

Diversity and abundance. We recorded a total of 17,146 immature Simuliidae individuals (last-instar larvae and pupae) which were identified into eleven species, as follows: Simulium pertinax Kollar; Simulium incrustatum Lutz; Simulium subpallidum Lutz; Simulium orbitale Lutz; Simulium rubrithorax Lutz; Simulium jujuyense Paterson \& Shannon; Simulium subnigrum Lutz; Simulium perflavum Roubaud; Simulium inaequale (Paterson \& Shannon); Simulium spinibranchium Lutz and Simulium lutzianum Pinto.

Mouth stretches from the nine studied streams of the Comandaí river, in the hydrographic region of the upper Uruguay river, were the ones of highest number of immature stages, representing $44.38 \%$ from all sampled individuals, followed by the intermediate stretches (29.09\%) and sources (25.72\%).

Simulium pertinax (77.55\%), followed by $S$. incrustatum (14.56\%) and S. subpallidum (2.35\%) were the most abundant species, representing $94.46 \%$ of the sampled simuliids (Table $1)$. The other species were far less frequent, representing only $5.64 \%$ of the total.

In general, S. pertinax was the most abundant species, represented by 13,298 individuals and with the highest frequency of occurrence (98.15\%), widely distributed along the water courses of the Comandaí river sub-basin. S. pertinax showed a greater association with river mouth of sampling points, where $40.73 \%$ of the total individuals were sampled. S. pertinax was also common in both seasons (Table 1).

Simulium incrustatum was the second most abundant species in this study, totaling 2,498 sampled individuals and occurred very frequently, reaching $\mathrm{FO}=88.01 \%$ during spring, predominantly in the intermediate stretches of streams, where it represented $38.98 \%$ of the total sampled individuals, as shown in Table 1.

Simulium subpallidum was the third most abundant species, totaling 404 individuals. Its distribution occurs similarly in both seasons, with 210 specimens (51.98\%) during spring and 194 (48.01\%) during autumn, predominantly in stretches close to the river mouth of streams (50.74\%), followed by the intermediate sections (31.11\%).

When analyzing the temporal distribution of simuliids we can see that most species occurred in both seasons. However, $S$. perflavum and S. lutzianum were found only in autumn and spring, respectively (Table 1).

Regarding the spatial distribution of species over large areas of the sub-basin, only S. spinibranchium and S. lutzianum were not found in all three regions (Upper, Middle, Lower). S. spinibranchium occurred only in streams located in the middle and lower region, while S. lutzianum, with only one sampled specimen, was found in the lower region of the subbasin, as shown in Figure 2.

The streams' river mouths showed a greater abundance of simuliids, comprising 7,610 (44.38\%) individuals, followed by intermediate stretches with $5,128(29.9 \%)$ and from the sources, with 4,408 individuals (25.72\%) (Figure 2).

The Fundão (Fu) and Giruá (Gi) streams showed the higher abundances among all nine sampled streams, corresponding, respectively, to $21.24 \%$ and $19.21 \%$ of all sampled individuals. Spring was the season with higher abundance in these two streams, totaling 1,687 (16.72\%) individuals in Fundão (Fu) and 1,533 (15.19\%) in Giruá (Gi). When comparing 
Table 1. Number of preimaginal Simuliidae individuals, capture proportion, frequency of occurrence, occurrence in streams' stretches and regions from the Comandaí River sub-basin, RS, Brazil, and presence by season, from September 2016 to July 2017.

\begin{tabular}{|c|c|c|c|c|c|c|}
\hline Species & $\begin{array}{c}\mathrm{N}^{\circ} \text { of } \\
\text { individuals }\end{array}$ & $\begin{array}{c}\text { \%PC } \\
\text { (stretches) }\end{array}$ & $\begin{array}{c}\% F O \\
\text { (stretches) }\end{array}$ & $\begin{array}{l}\text { Streams' } \\
\text { Stretches }\end{array}$ & $\begin{array}{l}\text { Region of the } \\
\text { basin }\end{array}$ & Season \\
\hline Simulium pertinax & 13.298 & 77.55 & 98.15 & $1,2,3$ & $A, M, B$ & $\mathrm{P}, \mathrm{O}$ \\
\hline Simulium incrustatum & 2.498 & 14,56 & 83.33 & $1,2,3$ & $A, M, B$ & $\mathrm{P}, \mathrm{O}$ \\
\hline Simulium subpallidum & 404 & 2,35 & 77.77 & $1,2,3$ & $A, M, B$ & $\mathrm{P}, \mathrm{O}$ \\
\hline Simulium orbitale & 324 & 1,89 & 27.77 & $1,2,3$ & $A, M, B$ & $\mathrm{P}, \mathrm{O}$ \\
\hline Simulium rubrithorax & 297 & 1,73 & 22.22 & $1,2,3$ & $A, M, B$ & $P, O$ \\
\hline Simulium jujuyense & 217 & 1,26 & 55.55 & $1,2,3$ & $A, M, B$ & $\mathrm{P}, \mathrm{O}$ \\
\hline Simulium subnigrum & 55 & 0,32 & 25.93 & $1,2,3$ & $A, M, B$ & $\mathrm{P}, \mathrm{O}$ \\
\hline Simulium perflavum & 28 & 0,16 & 14.81 & $1,2,3$ & A, M, B & $\mathrm{O}$ \\
\hline Simulium inaequale & 22 & 0,12 & 27.77 & $1,2,3$ & $A, M, B$ & $\mathrm{P}, \mathrm{O}$ \\
\hline Simulium spinibranchium & 2 & 0,01 & 3.70 & 1,2 & $\mathrm{M}, \mathrm{B}$ & $\mathrm{P}, \mathrm{O}$ \\
\hline Simulium lutzianum & 1 & 0,005 & 1.85 & 3 & B & $\mathrm{P}$ \\
\hline
\end{tabular}

Legend: $P C=$ capture proportion. $F O=$ frequency of occurrence. Streams' stretches (1=sources, 2=intermediate, 3=mouth). Region of the basin ( $A=$ upper, $M=$ middle, $B=l o w e r)$. Season ( $P=$ spring, $O=$ autumn).
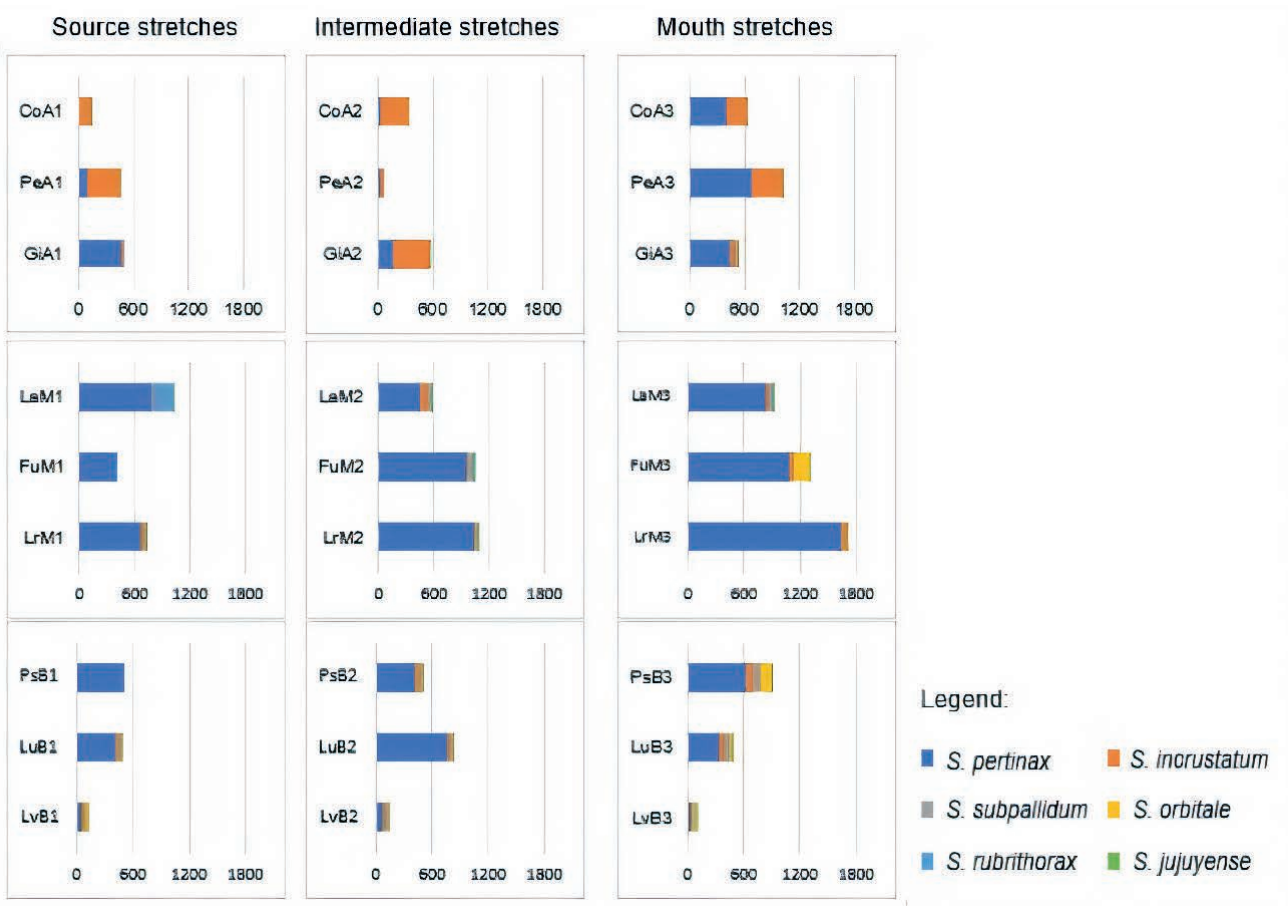

Figure 2. Abundance of the six most frequent simuliids species in relation to the stream stretch, during spring and autumn (2016-2017), in the regions of the Comandaí river sub-basin, RS, Brazil.

the sampled sections, the Giruá stream showed a greater abundance (548) in the intermediate section, while Fundão had a higher abundance in the mouth section, totaling 961 individuals

The Laranjeira stream (Lr) showed a greater abundance of simuliids during autumn, totaling 1,956 (27.70\%) individuals, when most individuals were found in the mouth section (57.41\%). We observed a prevalence of S. pertinax in that site, represented by 1,093 (97.32\%) specimens.

In the Lavínea stream (LV), we observed the lowest simuliid abundance among all streams (2.07\%), with 307 specimens (3.04\%) during spring and 49 (0.69\%) during autumn, with a greater abundance in the intermediate section (35.95\%) and source section (33.14\%).

The highest richness recorded in a single sampling point was eight species, in PsB3, in both seasons. The lowest richness was of one species, recorded in three sampling points
(CoA1, PeA2 and PsB1), two in source regions and one in an intermediate section, during autumn.

Regarding the diversity, no significant space-time interactions were found among the seasons and stretches $(P>0.05)$. However, significant differences were observed in the composition when evaluating factors separately. Spatially, we observed significant differences among stretches (PERMANOVA; pseudo-F = 2.07, $p<0.05$; Table 2), where source and river mouth stretches exhibited different species compositions (Table 3). Temporally, autumn and spring also showed differences in species diversity (pseudo- $F=5.02, p<$ 0.05; Table 2).

Some species are also indicators of certain seasons and of certain stretches. Temporally, while the species S. incrustatum, S. jujuyense and S. orbitale were indicators for the Spring $(\mathrm{P}<$ $0.05)$, S. perflavum was an indicator of the Autumn season ( $P$ $<0.05$ ) (Table 4). 
Table 2. PERMANOVA results from bi-factor analysis to assess species differences between groups $(p<0.05)$.

\begin{tabular}{cccccc}
$\begin{array}{c}\text { Stretches of } \\
\text { streams }\end{array}$ & 2 & 0.96 & 0.48 & 2.07 & $\mathbf{0 . 0 4 6}$ \\
Season & 1 & 1.16 & 1.16 & 5.02 & $\mathbf{0 . 0 0 1}$ \\
\hline Interaction & 2 & 0.52 & 0.26 & 1.13 & 0.315 \\
\hline
\end{tabular}

Table 3. PERMANOVA results. Paired comparisons with $T$ test. Numbers in bold showed a statistical difference $(P<0.05)$.

\begin{tabular}{ccc}
\hline Stretches of streams & $\mathbf{t}$ & $\mathbf{p}^{*}$ \\
\hline Source $x$ Intermediate & 1.00 & 0.37 \\
Source $\times$ Mouth & 1.74 & $\mathbf{0 . 0 2}$ \\
Intermediate $\times$ Mouth & 1.50 & 0.06 \\
\hline
\end{tabular}

Table 4. Result of the Monte Carlo significance test of the maximum value for indicator species per season. Bold values were statistically significant $(P<0.05)$.

\begin{tabular}{|ccc|}
\hline Species & Season & $\mathbf{p}^{*}$ \\
\hline S. pertinax & $\mathrm{P}$ & 0.5357 \\
\hline S. perflavum & $\mathrm{O}$ & $\mathbf{0 . 0 0 3 4}$ \\
\hline S. inaequale & $\mathrm{O}$ & $\mathbf{0 . 0 5 6 6}$ \\
\hline S. incrustatum & $\mathrm{P}$ & $\mathbf{0 . 0 0 0 2}$ \\
\hline S. subnigrum & $\mathrm{P}$ & $\mathbf{0 . 0 6 7 0}$ \\
\hline S. jujuyense & $\mathrm{P}$ & $\mathbf{0 . 0 0 8 0}$ \\
\hline S. subpallidum & $\mathrm{P}$ & 0.6321 \\
\hline S. rubrithorax & $\mathrm{O}$ & $\mathbf{0 . 0 5 2 2}$ \\
\hline S. orbitale & $\mathrm{P}$ & $\mathbf{0 . 0 0 0 2}$ \\
\hline
\end{tabular}

Legend: $\mathrm{O}=$ autumn; $\mathrm{P}=$ spring.

In relation to the stretches of streams, $S$. pertinax, $S$. jujuyense, S. subpallidum and S. orbitale species were indicator of river mouth stretches $(P<0.05)$ and S. rubrithorax was an indicator of sources, as shown in Table 5.

Table 5. Result of the Monte Carlo significance test of the maximum value of indicator species for stretches of the streams in the subbasin of the Comandaí River sub-basin, RS, Brazil. Bold values were statistically compromised $(\mathrm{P}<0.05)$.

\begin{tabular}{lcc}
\hline \multicolumn{1}{c}{ Species } & Stretches of streams & $\mathbf{p}^{*}$ \\
\hline S. pertinax & $\mathbf{3}$ & $\mathbf{0 . 0 4 9 6}$ \\
S. perflavum & 1 & 0.8844 \\
S. inaequale & 3 & 0.5597 \\
S. incrustatum & 3 & 0.7862 \\
S. subnigrum & 1 & 0.3939 \\
S. jujuyense & $\mathbf{3}$ & $\mathbf{0 . 0 5 3 8}$ \\
S. subpallidum & $\mathbf{3}$ & $\mathbf{0 . 0 2 8 6}$ \\
S. rubrithorax & $\mathbf{1}$ & $\mathbf{0 . 0 4 3 0}$ \\
S. orbitale & $\mathbf{3}$ & $\mathbf{0 . 0 0 0 2}$ \\
\hline
\end{tabular}

Legend: 1 = Source; $2=$ Intermediate e $3=$ Mouth.

Spatio-temporal variation of abundance and richness. Regarding the analysis of bi-factorial variation, no statistically significant interactions between stretches and seasons ( $p>$ 0.05), as well as among the factors isolated (Table 6; Figure 3).

When evaluating the richness, ANOVA does not show differences in the stretch versus season interaction $(P>0.05)$. However, differences were found when the factors were tested separately ( $P<0.05 ;$ Table 7). Spatially, a higher richness was observed in river mouth stretches when compared to source and intermediate stretches $(P<0.05$; Figure $4 A)$. Temporally, a greater richness was observed in Spring $(P<0.05$; Figure $4 B)$.

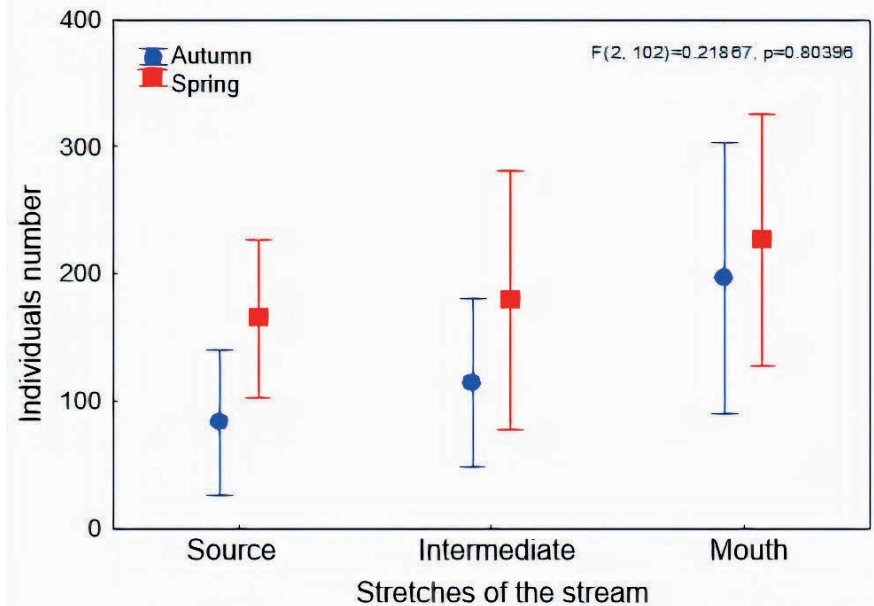

Figure 3. Analysis between the abundance of simuliids captured and stretches of the streams in the sub-basin of the Comandaí river, RS, Brazil, in the period between September 2016 and July 2017.

Table 6. Result of the variance analysis (ANOVA) for two-factor analysis of the simuliid abundance in the Comandaí river sub-basin, RS, Brazil, from September 2016 to July 2017.

\begin{tabular}{cccccc}
\hline Factor & SS & GL & MS & F & p* \\
\hline $\begin{array}{c}\text { Stretches of } \\
\text { streams }\end{array}$ & $1.48 \mathrm{E}+05$ & 2 & $7.41 \mathrm{E}+04$ & 2.563 & 0.082 \\
$\begin{array}{c}\text { Season } \\
\text { Stretches of }\end{array}$ & $9.39 \mathrm{E}+04$ & 1 & $9,39 \mathrm{E}+04$ & 3.247 & 0.074 \\
$\begin{array}{c}\text { streams x Season } \\
\text { tream }\end{array}$ & $1.26 \mathrm{E}+04$ & 2 & 6325 & 0.219 & 0.804 \\
\hline
\end{tabular}
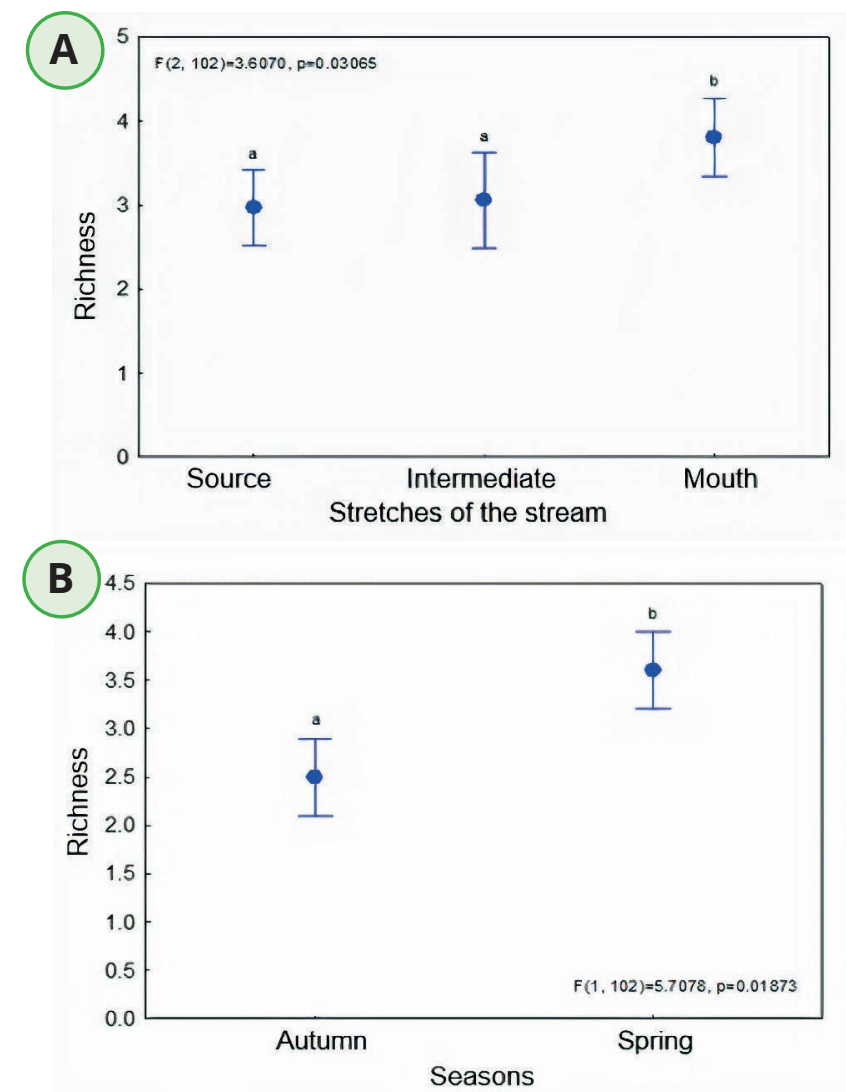

Figure 4. Analysis of simuliids richness when comparing stretches of streams (4A) and season (4B) based on individuals sampled in the Comandaí river sub-basin, RS, Brazil, from September 2016 to July 2017. 
Table 7. Two-way ANOVA test for species richness from the sub-basin of the Comandaí river, RS, Brazil, collected between September 2016 and July 2017.

\begin{tabular}{cccccc}
\hline Factor & SS & GL & MS & F & $\mathbf{p *}^{*}$ \\
\hline $\begin{array}{c}\text { Stretches of } \\
\text { streams }\end{array}$ & 15.17 & 2 & 7.58 & 3.607 & $\mathbf{0 . 0 3 1}$ \\
$\quad$ Season & 12 & 1 & 12 & 5.708 & $\mathbf{0 . 0 1 9}$ \\
$\begin{array}{c}\text { Stretches of } \\
\text { streams x Season }\end{array}$ & 2.06 & 2 & 1.03 & 0.489 & 0.615 \\
\hline
\end{tabular}

Relation with environmental variables. The forward selection method selected six abiotic variables from the total measured variables: altitude, stream width, vegetation cover, electrical conductivity, dissolved oxygen, and temperature.

The CCA explained $36.5 \%$ of the total data variability $(19.5 \%$ CCA 1 and $17.0 \%$ of CCA 2) and showed a relationship between biotic and abiotic variables in both axes ( $P<0.05$, Table 8$)$. CCA1 segregated Spring from Autumn, where S. incrustatum was more related to Spring $(r=0.48 ; p<0.05)$, which was characterized by a lower electrical conductivity. CCA2, on the other hand, segregated the stretches of highest altitude and vegetation coverage from the mouth stretches, which were wider. The spring stretches were related to the lower side of the biplot, associated with S. rubrithorax $(r=-0.61 ; p<0.05)$. The river mouth stretches were related to the positive side of the CCA2 biplot, as well as the species $S$. orbitale $(r=0.40 ; p$ $<0.05$ ). (Figure $5 A$ and $B$ ).

Table 8. Result of the canonical correspondence analysis (CCA) associating the abiotic variables selected by the forward selection, with the abundances of simuliid species from the Comandai river sub-basin, RS, Brazil, between September 2016 and July 2017. Values in bold $(P<0.05)$.

\begin{tabular}{lcc}
\hline & Axis 1 & Axis 2 \\
\hline Eigenvalues & 0.037 & 0.024 \\
$\begin{array}{l}\text { Cumulative\% of the explained variance of } \\
\text { the species - environment relationship }\end{array}$ & 19.5 & 17.0 \\
\hline $\begin{array}{l}\text { Species - Environmental Correlation ( } r \text { ) } \\
\text {. }\end{array}$ & $\mathbf{0 . 9 0 1}$ & $\mathbf{0 . 7 6 0}$
\end{tabular}

\begin{tabular}{lcc}
\hline Correlations of environmental variables with the ordering axes \\
\hline Altitude & 0.38 & $\mathbf{- 0 . 6 5}$ \\
Electrical Conductivity & $\mathbf{- 0 . 4 1}$ & 0.40 \\
\hline Stream width & 0.07 & $\mathbf{0 . 6 5}$ \\
Dissolved Oxygen & -0.19 & -0.37 \\
Coverage & 0.24 & $\mathbf{- 0 . 5 9}$ \\
Temperature & -0.33 & 0.32 \\
\hline
\end{tabular}

\section{DISCUSSION}

The region of the Uruguay river sub-basin is characterized by land use based on agricultural practices, mainly after the 1970s (Tuccı et al. 2003). In the study area, pig farming and milk production currently predominate. These anthropic actions, added to the natural characteristics of the lotic environment and biotic factors (such as predation and co-occurrence of species), can influence the local diversity and abundance of simuliids, as well as the structure and composition of all aquatic organisms (COPPO \& LOPES 2010; WAINFAS 2015; SANTOS \& MARINHO 2021).

The simuliid richness observed in the Comandaí river subbasin represents $39.28 \%$ of all the reported species for the state of Rio Grande do Sul, and $6.79 \%$ of the total sampled species current reported for Brazil (AdLer 2021). From the eleven sampled species in this study, S. pertinax $(77.55 \%)$ showed the highest abundance and frequency of occurrence, a similar result was observed in other studies carried out in several other watersheds from Rio Grande do Sul (Strieder 2004; Strieder et al. 2006; Santos et al. 2007; Bertazo et al. 2013; Couceiro et al. 2014; Menzel et al. 2019), as well as in other Brazilian states (Cunha 2004; Lozovel et al. 2004; Coppo \& LoPES 2010; Aranda 2017; Figueiró et al. 2020). This species adapts easily to different micro-habitats, and currently occurs in 17 of the 27 Brazilian states, in addition to other South American countries such as Argentina, Bolivia and Paraguay (AdLeR 2020).
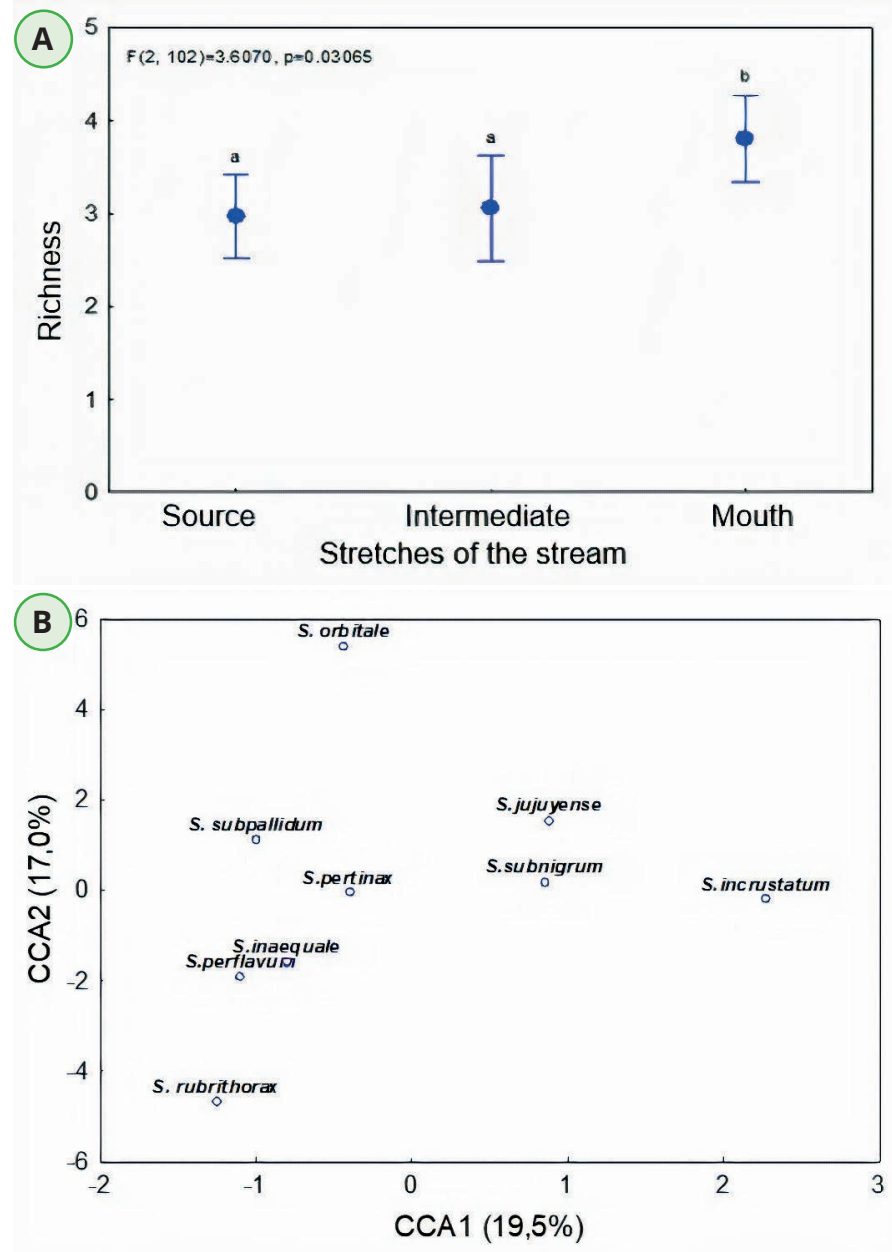

Figure 5. Result of the Canonical Correspondence Analysis applied to the data matrix of simuliids and abiotic parameters sampled in the Comandaí river sub-basin, RS, Brazil, between September 2016 and July 2017.

Simulium pertinax was found in all sampling points and was more associated with mouth stretches in streams, differently from the results obtained by Menzel (2019) for the Piratinim river basin, in the Pampa biome, where the highest abundance was recorded in source stretches. These results, obtained in Comandaí river sub-basin, may be related to the greater environmental homogeneity caused by anthropogenic actions. Hentges et al. (2021) state that in the Piratinim river basin, environmental conditions close to biological integrity predominate.

Simulium incrustatum (14.56\%) was the second most abundant species in this study and, along with S. pertinax, represented $92.11 \%$ of the total sample, also showing a wide distribution within the sampled streams, which corroborate previous studies (Docile et al. 2015; YA'coв et al. 2016; Menzel et al. 2019). The occurrence of this species was higher in the source and in the upper region of the sub-basin.

Simulium pertinax and S. incrustatum were also the most 
abundant species in a study carried out in the Caí river basin, in Rio Grande do Sul, where two areas were compared: one with a reduced impact and the other with a greater environmental impact (StRIEDER et al. 2006). In the tributaries of the Paquequer river in Rio de Janeiro state, the prevalence and association of S. incrustatum and S. pertinax was observed, with intermediate levels of pollution (DocILE et al. 2015). In the state of São Paulo, in a study conducted by VIVIANI et al. (2012), S. incrustatum also showed a greater association with intermediate levels of pollution.

According to Coscarón (1991) and Strieder \& Corseuil (1992), S. incrustatum and S. pertinax are the most harmful species to the well-being of human communities, both in the South and in other regions of Brazil, due to the discomfort caused by bites that can result from mild allergic reactions to inflammatory processes that require medication. However, species that benefit from aquatic environments in conditions of organic contamination, such as $S$. pertinax, can also be considered as bioindicators of water quality (Pedroso-De-PAIVA \& BRANCO 2000; VIVIANI et al. 2012).

Simulium subpallidum was the third most abundant species, being more frequent in stretches from the mouth of the streams (50.74\%), which generally have greater width and less current. These results coincide with studies carried out by CosCARón (1991) and FIGUEIRó et al. (2008), who reported the preference of this species for low-flow water courses. However, PepineluI (2003) also collected this species in streams of greater current. Other authors found an association of $S$. subpallidum with the rainiest period of the year (FIGUEIRó et al. 2014) and waters with an intermediate environmental impact (Docile et al. 2015). This species occurs in 19 Brazilian states, in addition to other countries such as Argentina, Guyana, Paraguay, Uruguay and Venezuela (Adler 2020).

The fact that only few species were expressive in abundance is in accordance with the results obtained by McGILL et al. (2007) and several other studies regarding immature stages of simuliids (Strieder et al. 2006; SAntos et al. 2010; Aranda 2017; Menzel et al. 2019; JitKLANG et al. 2020), suggesting that environments modified by economic activities are more homogeneous (Couceiro et al. 2014). In the Comandaí river sub-basin, a higher abundance of simuliids (44.38\%) was observed in mouth stretches. This result is in accordance with COPPo \& Lopes (2010), who, in an investigation carried out on the Paraná river, associated a greater abundance of simuliids in stretches of streams with a higher rate of environmental degradation.

The higher richness found in this study was of eight species, observed in two sampling points. This result is similar to studies such as LANDEIRO et al. (2009), who recorded the same richness in Mucugê, Chapada Diamantina, and Menzel et al. (2019), which reported seven species in five sampling points in the ljuí river basin, Rio Grande do Sul. HAmADA et al. (2002) and Pepinell et al. (2005) suggested that these numbers are relatively high when compared to other regions of Brazil.

The results regarding the average species richness, when observed by streams' stretches (sampling point) were lower (4.74 for Spring; 4.03 for Autumn) than the general analysis grouped by streams (5.09 for Spring; 5.36 for Autumn). In other studies, a similar average richness was observed during Spring, with 5.44 for the Piratinim river basin and 4.25 for 39 streams in disturbed areas in the eastern and western regions of the state of Rio Grande do Sul (Couceiro et al. 2014; Menzel et al. 2019). The average richness found in studies conducted in South Brazil are high in relation to the other regions of Brazil (HAMADA et al. 2002; LANDEIRO et al. 2009).

Species diversity has practically not changed between seasons, which corroborates other studies on the temporal distribution of Simuliidae, where no major changes in species diversity were found (GRILlet \& Barrera 1997; SANTOS et al. 2010). Such findings suggest that changes in species composition are more related to local geomorphology and environmental factors, in addition to the degree of the environment's conservation status (Strieder et al. 2006).

A higher simuliid abundance obtained during the Spring coincides with three other studies carried out in the southern region of Brazil: Strieder \& CoRseuil (1992) in Sapiranga, Rio Grande do Sul; Santos et al. (2010) in Londrina, Paraná; and Menzel (2019), in the Piratinim river basin, Pampa biome. However, it differs from the findings of FigueIRó et al. (2006) in the Itatiaia National Park, Rio de Janeiro, where the four seasons of the year were analyzed, and the highest abundances were found during Summer and Autumn.

Under a spatial analysis, four species were considered indicators for mouth stretches (S. pertinax, S. jujuyense, S. subpallidum and S. orbitale), while $S$. rubrithorax was considered an indicator for sources stretches. The point with the higher occurrence of S. rubrithorax for the Comandaí river sub-basin meet the findings of COSCARón (1991), who indicated that the species has a preference for lotic environments with fast currents in small water courses. Source stretches of the streams in this study present relatively conserved riparian vegetation, with rocky bottoms, and land use in the neighboring areas is predominantly based on activities such as dairy farming and agriculture.

In this study we verified that environmental variables such as conductivity, altitude, canopy coverage and stream width are important conditioning factors for the local distribution of immature simuliids. In this context, the results on the local distribution and abundance of simuliids may have been influenced by the geomorphological characteristics and anthropic actions on the lotic environments from the study area. Our findings may be useful to the application of efficient control measures for species of health and sanitary importance in southern Brazil.

\section{ACKNOWLEDGEMENTS}

The authors are thankful to the Universidade Federal de Fronteira Sul - Cerro Largo campus, for logistical support during the performance of this study.

\section{REFERENCES}

Adler, PH \& KC Kim, 1984. Ecological characterization of two sibling species, IIIL-1 and IS-7, in the Simulium vittatum complex (Diptera: Simuliidae). Canadian Journal of Zoology, 62: 1308-1315. DOI: https://doi.org/10.1139/z84188

Adler, PH \& JW McCreadie, 2019. Black flies (Simuliidae), pp. 237-259. In: Mullen G \& Durden L (Eds.). Medical and veterin ary entomology. Academic Pressp. 237-259. DOI: https://doi.org/10.1016/B978-0-12-814043-7.00014-5

Adler, PH, 2020. World blackflies (Diptera: Simuliidae): A review of the taxonomic and geographic inventory.

Adler, PH, 2021. World blackflies (Diptera: Simuliidae): A comprehensive revision of the taxonomic and geographical inventory. Department of plant and Environmental Sciences, Cleemson, South Carolina, USA.

Aranda, AT, 2017. Composição e distribuição da simuliofauna (Diptera: Simuliidae) em Remanescente de Mata Atlântica no Zoneamento Ambiental do Parque Estadual da Pedra Branca, Rio de Janeiro, RJ, Brasil. Dissertação (Mestre em Biodiversidade e Saúde). Instituto Oswaldo Cruz.

Araújo-Coutinho, CJPC, RP Mello \& NMS Freire, 1999. Larval Preference of Psaroniocompsa incrustata (Lutz, 1910) 
(Diptera: Simuliidae) for Different Colors of Artificial Substrates in Breeding Grounds, at Pium River, State of Rio Grande do Norte, Brazil. Memórias do Instituto Oswaldo Cruz, Rio de Janeiro, 94: 849-850. DOI: https://doi.org/10.1590/S0074-02761999000600026

Baptista, VA, MB Antunes, AR Martello, NSB Figueiredo, AMB Amaral, E Secretti \& B Braun, 2014. Influence of environmental factors on the distribution of families of aquatic insects in rivers in southern Brazil. Ambiente \& Sociedade, 17: 153-174. DOI: https://doi.org/10.1590/ S1414-753X2014000300010

Bertazo, K, N Hamada \& FF Salles, 2013. Fauna of Simuliidae (Diptera) from the state of Espírito Santo, Brazil: distribution, new records and list of species. Revista Brasileira de Entomologia, 57: 91-99. DOI: https://doi.org/10.1590/S0085-56262013000100014

Brasil, 2011. Plano Nacional de Recursos Hídricos: Prioridades 2012-2015. Available in: <https://www.ceivap.org.br/ ligislacao/Resolucoes-CNRH/Plano_Nacional-de-RecursosHidricos.pdf>.

Busari, LO, O Ojurongbe, MA Adeleke, OA Surakat \& AA Akindele, 2021. Biting behaviour and infectivity of Simulium damnosum complex with Onchocerca parasite in Alabameta, Osun State, Southwestern, Nigeria. PLOS ONE, 16: 1-9. DOI: https://doi.org/10.1371/journal. pone.0252652

Coppo, TL \& J Lopes, 2010. Diversidade de Simuliidae (Diptera: Nematocera) de três cursos d'água no parque ecológico da Klabin S.A. - Telêmaco Borba, Estado do Paraná. Semina: Ciências Biológicas e da Saúde, 31: 03-14. DOI: https://doi.org/10.5433/1679-0367.2010v31n1p03

Coscarón, S, 1991. Insecta, Diptera, Simuliidae: Fauna água dulce de la República Argentina. 2 ed. Buenos Aires: Fecic.

Corkum, LD \& DC Currie, 1987. Distributional patterns of immature Simuliidae (Diptera) in northwestern North America. Freshwater Biology, 17: 201-221. DOI: https://doi.org/10.1111/j.1365-2427.1987.tb01043.x

Coscarón, S, SI Bernal \& CL Arias, 1996. Revisión de Simulium (Psilopelmia) Enderlein en la región Neotropical y análisis cladístico de sus especies (Diptera: Simuliidae). Acta Zoologica Mexicana, 69: 37-104.

Couceiro, S, N Hamada, L Sagot \& M Pepinelli, 2014. Blackfly assemblage distribution patterns in streams in disturbedareas in southern Brazil. Acta Tropica, 140: 2633. DOI: https://doi.org/10.1016/j.actatropica.2014.07.018

Crosskey RW, 1990. The Natural History of Blackflies. Reino Unido. John Wiley \& Sons Ltd.

Cunha, ABPV, 2004. Variação temporal e sazonal se larvas de Simulium sp. no litoral norte do estado de São Paulo. 2004. Dissertação (Mestrado em Aquicultura), Universidade Estadual Paulista, Jaboticabal.

Currie, DC \& PH Adler, 2008. Global diversity of black flies (Diptera: Simuliidae) in freshwater. Developments in Hydrobiology, 595: 469-475. DOI: https://doi.org/10.1007/ s10750-007-9114-1

Docile, TN, R Figueiró, LH Gil-Azevedo \& JL Nessimian, 2015. Water Pollution and Distribution of the Black Fly (Diptera: Simuliidae) in the Atlantic Forest, Brazil. Revista de Biología Tropical, 63: 683-693.

Dora, A, 2013. Quantificação de reservas renováveis de água subterrânea em bacias hidrográficas a partir de séries históricas de vazão: uma ferramenta para gestão de bacias. (Monografia Engenharia Ambiental) Universidade Federal do Rio Grande do Sul.

Ferreira, VMB, JLDC Souza \& M Moraes, 2020. Estrutura da comunidade de macroinvertebrados bentônicos em diferentes tipos de habitats em um trecho de rio de Mata Atlântica. Research, Society and Development, 9: 1-13. DOI: https://doi.org/10.33448/rsd-v9i1.1848

Figueiró, R, CJPC Araújo-Coutinho, LH Gil-Azevedo, ES Nascimento \& RF Monteiro, 2006. Spatial and temporal distribution of blackflies (Diptera: Simuliidae) in the Itatiaia National Park, Brazil. Neotropical Entomology, 135: 542-550. DOI: https://doi.org/10.1590/S1519$566 \times 2006000400018$

Figueiró, R, ÉSD Nascimento, LH Gil-Azevedo, M MaiaHerzog \& RF Monteiro, 2008. Local distribution of blackfly (Diptera, Simuliidae) larvae in two adjacente streams: the role of water current velocity in the diversity of blackfly larvae. Revista Brasileira de Entomologia, 52: 452-454. DOI: https://doi.org/10.1590/S0085-56262008000300020

Figueiró, R, LH L-Azevedo, M Maia-Herzog \& RF Monteiro, 2012. Diversity and microdistribution of black fly (Diptera: Simuliidae) assemblages in the tropical savanna streams of the Brazilian cerrado. Memórias do Instituto Oswaldo Cruz, 107: 362-369. DOI: https://doi.org/10.1590/S007402762012000300011

Figueiró, R, M Maia-Herzog, LH Gil-Azevedo \& RF Monteiro, 2014. Variação sazonal em taxocenoses de mosca negra (Diptera: Simuliidae) do Cerrado Brasileiro (Tocantins, Brasil). Journal of Vector Ecology, 39: 321-327. DOI: https://doi.org/10.1111/jvec.12107

Figueiró, R, A Calvet, LH Gil-Azevedo, TN Docile, RF Monteiro \& M Maia-Herzog, 2015. Evidence of Phenotypic Plasticity of Larvae of Simulium subpallidum Lutz in different streams from the Brazilian Cerrado. Revista Brasileira de Entomologia, 59: 28-31. DOI: https://doi.org/10.1016/j. rbe.2015.02.003

Figueiró, R, SS Santos, TN Docile, T Costa, CA Ferreira \& LH Gil-Azevedo, 2020. Preliminary observations on the patterns of co-occurrence of Black fly (Diptera: Simuliidae) larvae and some of their potential macroinvertebrate predators. Revista Brasileira de Entomologia, 64: 1-6. DOI: https://doi.org/10.1590/1806-9665-RBENT-2020-0046

Figueiró, R \& LH Gil-Azevedo, 2010. The role of the Neotropical blackflies (Diptera: Simuliidae) as vectors of the onchocerciasis: a short overview of the ecology behind the disease. Oecologia Australis, 14: 745-755. DOI: https://doi.org/10.4257/oeco.2010.1403.10

Fleming, EL, G Lim \& JM Wallace, 1986. Differences between the Spring and Autumn Circulation of the Northern Hemisphere. Journal of the Atmospheric Sciences, 44: 1266-1286. DOI: https://doi.org/10.1175/15200469(1987)044<1266:DBTSAA>2.0.CO;2

Grillet, ME \& R Barrera, 1997. Abundância espacial e temporal, partição de substrato e coocorrência de espécies em uma guilda de moscas-pretas neotropicais (Diptera: Simuliidae). Hydrobiologia, 345: 197-208. DOI: https://doi.org/10.1023/A:1002901612957

Hamada, N, JW McCreadie \& PH Adler, 2002. Species richness and spatial distribution of blackflies (Diptera: Simuliidae) in streams of Central Amazonia, Brazil. Freshwater Biology, 47: 31-40. DOI: https://doi.org/10.1046/j.13652427.2002.00778.x

Hamada, N \& JW McCreadie, 1999. Environmental factors associated with the distribution of Simulium perflavum (Diptera: Simuliidae) among streams in Brazilian Amazonia. Hydrobiologia, 397: 71-78. DOI: https://doi.org/10.1023/A:1003642430681

Hamada, N, JW McCreadie \& PH Adler, 2002. Species richness and spatial distribution of blackflies (Diptera: Simuliidae) in streams of Central Amazonia, Brazil. Freshwater Biology, 47: 31-40. DOI: https://doi.org/10.1046/j.13652427.2002.00778.x

Hentges SM, TC Menzel, CM Loebens, SE Siveris, DA Reynalte-Tataje \& MN Strieder, 2021. Structure of aquatic macroinvertebrate communities in streams of a sub-basin in the Pampa Biome, Southern Brazil. Neotropical Biology and Conservation, 16: 249-271. https://doi.org/10.3897/ neotropical.16.e60579

Jacob, B, D Loum, D Munu, T Lakwo, E Byamukama, P Habomugisha, EW Cupp \& TR Unnasch, 2021. 
Optimization of Slash and Clear Community-Directed Control of Simulium damnosum Sensu Stricto in Northern Uganda. The American Journal of Tropical Medicine and Hygiene, 104: 1394-1403. DOI: https://doi.org/10.4269/ ajtmh.20-1104

Jitklang, S, W Sawangproh, C Kuvangkadilok, V Baimai \& PH Adler, 2020. Ecology of black flies (Diptera: Simuliidae) in streams of northern and southern Thailand: Factors associated with larval and pupal distributions. Acta Tropica, 204: 1-49. DOI: https://doi.org/10.1016/j. actatropica.2020.105357

Kiel, E, F Böge \& W Rühm, 1998. Sustained effects of larval blackfly settlement on further substrate colonisers. Archiv fur Hydrobiologie, 141: 153-166. DOI: https://doi.org/10.1127/archiv-hydrobiol/141/1998/153

Landeiro, VL, M Pepinelli \& N Hamada, 2009. Species richness and distribution of blackflies (Diptera: Simuliidae) in the Chapada Diamantina region, Bahia, Brazil. Neotropical Entomology, 38: 332-339. DOI: https://doi.org/10.1590/ S1519-566X2009000300006

López-Peña, D, FM Hawkes, GI Gibson, C Johnston, AGC Vaux, Á Lis-Cantín \& RA Cheke, 2021. Mosquito Magnet ${ }^{\circledR}$ traps as a potential means of monitoring blackflies of medical and veterinary importance. Medical and Veterinary Entomology, pp. 1-6 DOI: https://doi.org/10.1111/ mve. 12530

Lozovei, AL, F Petry, NLG Santos \& ME Ferraz, 2004. Levantamento das espécies de Simulium (Diptera, Simuliidae), Riacho dos Padres, município de Almirante Tamandaré, Paraná, Brasil. Revista Brasileira de Entomologia, 48: 91-94. DOI: https://doi.org/10.1590/ S0085-56262004000100015

Malmqvist, B, Y Zhang \& PH Adler, 1999. Diversity, distribution and larval habitats of North Swedish blackflies (Diptera: Simuliidae). Freshwater Biology, 42: 301-314. DOI: https://doi.org/10.1046/j.1365-2427.1999.444497.x

McCreadie, JW \& PH Adler, 2006. Ecoregions as predictors of lotic assemblages of blackflies (diptera: Simuliidae). Ecography, 29: 603-613. DOI: https://doi.org/10.1111/ j.0906-7590.2006.04541.x

McGill, BJ, RS Etienne, JS Gray, D Alonso, MJ Anderson, HK Benecha, M Dornelas, BJ Enquist, JL Green, $\mathrm{F} \mathrm{He}, \mathrm{AH}$ Hurbert, AE Magurran, PA Marquet, BA Maurer, A Ostling, CU Soykan, KI Uglanf \& EP White, 2007. Species abundance distributions: moving beyond single prediction theories to integration within an ecological framework. Ecology Letters, 10: 995-1015. DOI: https://doi.org/10.1111/j.14610248.2007.01094.x

Menzel, TC, 2019. Distribuição Espacial e Temporal de Simuliidae (Diptera: Culicomorpha) em uma Bacia Hidrográfica do Bioma Pampa, no Sul do Brasil. (Master in Ambiente e Tecnologias Sustentáveis). Universidade Federal da Fronteira Sul.

Menzel, TC, SM Hentges, DAR Tataje \& MN Strieder, 2019. Diversity and spatial distribution of black flies (Diptera: Simuliidae) in the ljuí river drainage basin, Rio Grande do Sul, Brazil. Entomobrasilis, 12: 47-56. DOI: https://doi.org/10.12741/ebrasilis.v12i2.845

Moreira, GRP, RA Pegoraro \& G Sato, 1994. Influência de fatores abióticos sobre o desenvolvimento de Simulium nogueirai D’Andreatta \& González em um córrego da mata Atlântica. Anais da Sociedade Entomológica do Brasil, 23: 525-542. DOI: https://doi.org/10.37486/03018059.v23i3.978

Pavitra, SP, LV Low, TK Tan, YAL Lim, Z Ya'cob, 2020. Temporal variation in diversity and community structure of preimaginal blackflies (Diptera: Simuliidae) in a tropical forest reserve in Malaysia. Acta tropica, 202: 105275. DOI: https://doi.org/10.1016/j.actatropica.2019.105275

Pedroso-De-Paiva, D \& EPO Branco, 2000. Borrachudo: Noções Básicas de Biologia e Controle. Concórdia: Embrapa.
Pepinelli, M, S Trivinho-Strixino \& N Hamada, 2003. Description of Simulium (Chirostilbia) friedlanderi PyDaniel, 1987 (Insecta: Diptera: Simuliidae) female. Biota Neotropica, 3: 1-6. DOI: https://doi.org/10.1590/S167606032003000200008

Pepinelli, M, S Trivinho-Strixino \& N Hamada, 2005. Imaturos de Simuliidae (Diptera, Nematocera) e caracterização de seus criadouros no Parque Estadual Intervales, SP, Brasil. 49: 527- 530. DOI: https://doi.org/10.1590/S008556262005000400012

Rio Grande do Sul, 2002. Atlas socioeconômico: Estado do Rio Grande do Sul, 2ed. Available in: <https:// atlassocioeconomico.rs.gov.br/15-anos-do-atlassocioeconomico-do-rs>

Santos Jr, JE, MN Strieder, GL Fiorentin \& UG Neiss, 2007. Velocidade da água e a distribuição de larvas e pupas de Chirostilbia pertinax (Kollar) (Diptera, Simuliidae) e macroinvertebrados associados. Revista Brasileira de Entomologia, 51: 62-67. DOI: https://doi.org/10.1590/ S0085-56262007000100011

Santos, RB, J Lopes \& KB Santos, 2010. Distribuição espacial e variação temporal da composição de espécies de borrachudos (Diptera: Simuliidae) em uma microbacia situada no norte do Paraná. Neotropical Entomology, 39: 289-298. DOI: https://doi.org/10.1590/S1519$566 \times 2010000200022$

Santos, RG \& WRC Marinho, 2021. Predileção de substrato por espécies hematófagas de Simuliidae (Diptera) da região sudeste do Brasil para controle vetorial. Nature and Conservation, 14: 1-11. DOI: http://doi.org/10.6008/ CBPC2318-2881.2021.001.0001

Sariözkan, S, A İnci, A Yildirim, O Düzlü, EW Gray \& PH Adler, 2014. Economic Losses During an Outbreak of Simulium (Wilhelmia) Species (Diptera: Simuliidae) in the Cappadocia Region of Turkey. Original Investigation, 38: 116-119. DOI: https://doi.org/10.5152/tpd.2014.3446

Shelley, AJ, LM Hernández, M Maia-Herzog, APA Luna Dias \& PR Garritano, 2010. The Blackflies (Diptera: Simuliidae) Of Brazil. In:JR Arias, S Golovatch, KM Wantzen \& E Dominguez (Eds). Aquatic Biodiversity in Latin America. Sofia: Pensoft Pub.

Srisuka, W, H Takaoka, Y Otsuka, M Fukuda, S Thongsahuan \& K Taai, 2015. Seasonal biodiversity of black flies (Diptera: Simuliidae) and elevation of ecological factors influencing species distribution at Doi Pha Hom Poh National Park, Thailand. Acta Tropica, 149: 212-219. DOI: https://doi.org/10.1016/j.actatropica.2015.05.024

Srisuka, W, C Sulin, K Aupalee, T Phankaen, K Taai, S Thongsahuan \& H Takaoka, 2021. Community Structure, Biodiversity and Spatiotemporal Distribution of the Black Flies (Diptera: Simuliidae) Using Malaise Traps on the Highest Mountain in Thailand. Insects, 12: 1-15. DOI: https://doi.org/10.3390/insects12060504

Strieder, MN \& E Corseuil, 1992. Atividades de hematofagia em Simuliidae (Diptera, Nematocera) na Picada Verão, Sapiranga, RS - Brasil. Acta Biologica Leopoldensia, 14: 7598.

Strieder, MN, 2004. Espécies de simulídeos (Diptera, Nematocera, Simuliidae) no Rio Grande do Sul, Brasil: distribuição geográfica. Entomología y Vectores, 11: 117121.

Strieder, MN, JE Santos \& EM Vieira, 2006. Distribuição, abundância e diversidade de Simuliidae (Diptera) em uma bacia hidrográfica impactada no sul do Brasil. Revista Brasileira de Entomologia, 50: 119-124. DOI: https://doi.org/10.1590/S0085-56262006000100018

Strieder, MN \& V Py-Daniel, 1999. Espécies de Inaequalium (Diptera, Simuliidae): dados bionômicos e chaves para sua identificação. Biociencias, 7: 43-72.

Tongjura, JDC, GA Amuga, HB Mafuyai, BM Matur \& JO Olatunwa, 2015. Influence of Some Water 
Physicochemical Parameters on the Distribution of Black Fly (Diptera, Simuliidae) in Some Rivers in Nasarawa State, Nigeria. Advances in Entomology, 3: 101-110. DOI: https://doi.org/10.4236/ae.2015.33012

Tucci, CEM, RT Clarke, W Collischonn, PLS Dias \& GS Oliveira, 2003. Long-term flow forecasts based on climate and hydrologic modeling: Uruguay River basin. Water Resources Research, 39: 1181. DOI: https://doi.org/10.1029/2003WR002074

Viviani, ABP, CJPC Araújo-Coutinho, RB Moraes, HB Gil, R Leung \& AFM Camargo, 2012. Distribuição e abundância de larvas de Simulium spp. em córregos do estado de São Paulo nos diferentes níveis de qualidade da água.
Neotropical Biology and Conservation, 7: 48-56. DOI: https://doi.org/10.4013/nbc.2012.71.07

Ya'cob, Z, H Takaoka, P Pramual, VL Low \& M SofianAzirun, 2016. Distribution pattern of black fly (Diptera: Simuliidae) assemblages along an altitudinal gradient in Peninsular Malaysia. Parasites \& Vectors, 9: 1-16. DOI: https://doi.org/10.1186/s13071-016-1492-7

Wainfas, RL, 2015. Distribuição espacial e temporal de Simuliidae (Diptera) em córregos sob a influência de fatores abióticos e antrópicos da área da UHE peixe angical, Tocantins, Brasil. (Master in Biodiversidade e Saúde). Instituto Oswaldo Cruz, Rio de Janeiro.
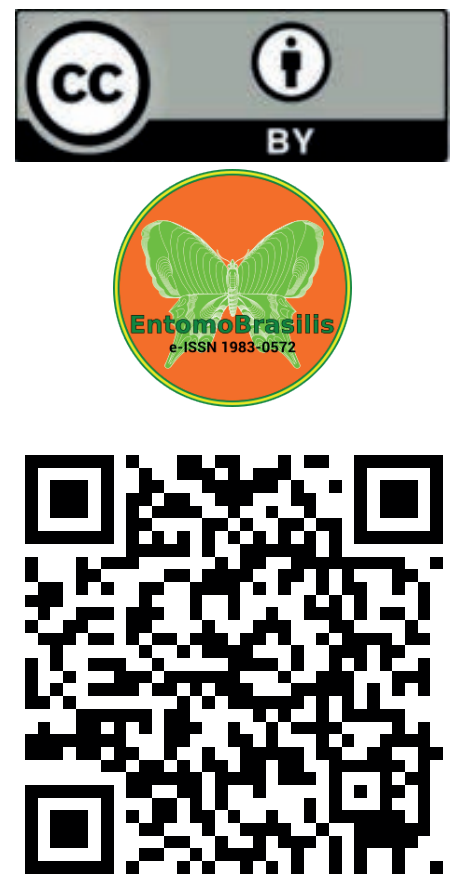